\title{
Prezydium Rady Ministrów w latach 1918-1939. Struktura, zakres kompetencji i działalność projektodawcza. (Zarys problemu)
}

Prezydium Rady Ministrów zostało utworzone z końcem 1917 r. przez Radę Regencyjną z chwilą powołania pierwszego premiera i przejęło funkcje istniejącego Biura Prezydialnego Tymczasowej Rady Stanu. Jednak działalność tego organu nie uzyskała dotychczas bardziej wyczerpującego opisu w literaturze naukowej. Opracowanie to jest próbą ukazania struktury, zakresu kompetencji i roli projektodawczej tego pomocniczego organu rządu. Podstawą stały się głównie materiały archiwalne zgromadzone w Archiwum Akt Nowych w Warszawie i bardzo nieliczne opracowania ${ }^{1}$.

Na wstępie należy zaznaczyć, że w omawianym okresie organizacja Rady Ministrów nie została w żadnym akcie ustawowo uregulowana, a jedyną podstawą prawną był dekret Rady Regencyjnej z 3 stycznia 1918 r., „o tymczasowej organizacji władz naczelnych w Królestwie Polskim"2.

${ }^{1}$ R. Hausner, Poczynania organizacyjno-oszczędnościowe w Polsce w latach 1918-1934, Warszawa 1935, s. 154-157; idem, O trybie przygotowania obowiqzujacych przepisów, Warszawa 1932, s. 32-33; J. Stojanowski, Archiwum Akt Nowych w Warszawie, (w:) Straty bibliotek i archiwów warszawskich w zakresie rękopiśmiennych źródet historycznych, Warszawa 1956, t. 2, s. 283-285.

${ }^{2}$ Należy podkreślić, że najważniejsze dekrety i ustawy, tj. dekret Naczelnika Państwa z 22.11.1918 r. „O najwyższej władzy reprezentacyjnej Republiki Polskiej”, mała konstytucja z 20.02.1919 r. „O organizacji i zakresie działania władz najwyższych” (która zastappiła dekret z 22.11.1918 r.), Konstytucja marcowa (dokładnie art. 63, w którym mowa o liczbie, zakresie działania i wzajemnym stosunku ministrów oraz o zakresie kompetencji rządu), „Nowela sierpniowa”, tj. ustawa z 2.08.1926 r. zmieniająca postanowienia Konstytucji marcowej, Konstytucja kwietniowa, gdzie w art. 25 zapowiadano wydanie dekretu Prezydenta RP o organizacji rządu i zakresie kompetencji premiera, Rady Ministrów i ministrów - nigdy nie zostały uzupełnione o rozporządzenia wykonawcze. Żaden z wyżej wymienionych aktów nie zawierał pojęcia „Prezydium Rady Ministrów”. Jedynymi aktami normującymi zasady funkcjonowania PRM były często zmieniające się rozporządzenia i uchwały rządu. Warto tutaj zacytować słowa sprawozdawcy Komisji Budżetowej Sejmu dr. Waleriana Zaklika, który w 1936 r. podsumował: „Konstytucja kwietniowa, tak samo zresztą jak marcowa nie zna organu: Prezydium Rady Ministrów. Pojęcie Prezydium byłoby właściwe dla emanacji jakiejś instytucji kolegialnej. Taką instytucją kolegialnąjest Rada Ministrów, ale nie 
Według R. Hausnera, Prezydium Rady Ministrów powstało w końcu 1917 r., a więc jeszcze w okresie funkcjonowania gabinetów w dobie Rady Regencyjnej ${ }^{3}$. Organ ten podlegał bezpośrednio premierowi i został zorganizowany jako oddzielna jednostka administracyjna, na czele której stał podsekretarz stanu, w randze wiceministra (któremu podlegały wszystkie biura PRM); stanowisko to zostało utrzymane (z niewielkimi przerwami) do końca II Rzeczypospolitej ${ }^{4}$.

Należy podkreślić, że zakres kompetencji Prezydium Rady Ministrów wynikał z uprawnień szefa rządu i stąd cała organizacja PRM musiała zostać dostosowana do prerogatyw premiera, aby usprawnić wszelkie działania koordynacyjne i organizacyjne. $Z$ tej zależności wynika konieczność ukazania zakresu kompetencji Prezesa Rady Ministrów, do których należały: reprezentowanie rządu, zwoływanie posiedzeń i kierowanie jego pracami, nadzorowanie jednolitej polityki rządu, nadzór nad działalnością ministrów i przestrzeganiem zakresu ich kompetencji, a szczególnie nadzór nad przygotowywaniem projektów ustaw, które miały normować organizację naczelnych organów państwowych $\mathrm{i}$ ich wzajemne relacje, nadzór nad przebiegiem prac w ramach inicjatywy ustawodawczej rządu oraz nad pracami w tworzeniu projektów rozporządzeń rządowych, czuwanie nad organizacją administracji państwa, w tym nad procesem podnoszenia kwalifikacji urzędników, czy urzędami podlegającymi bezpośrednio premierowi, a także informowanie głowy państwa o wykonaniu programu rządu i pozostawanie w zgodności poglądów na ogólną politykę państwa z prezydentem RP, informowanie parlamentu o programie politycznym Rady Ministrów, „czuwanie nad stosunkiem ciał ustawodawczych do rządu i nad biegiem prac ustawodawczych Sejmu i Senatu oraz nad współdziałaniem w tej pracy z rządem", czy informowanie prasy o podstawowych założeniach polityki rządu i wydawanie gazety jako organu prasowego Rady Ministrów 5 .

wyłania ona z siebie Prezydium; kieruje Radą jednoosobowo Prezes Rady Ministrów. Pojęcie Prezydium Rady Ministrów nie opiera się na Konstytucji, na jakimkolwiek akcie ustawodawczym, a jedynie uchwały Rady Ministrów to pojęcie tworzyły, ostatnio uchwała z 12 III 1930 r., która uchwaliła statut organizacyjny Prezydium Rady Ministrów", Archiwum Akt Nowych w Warszawie (cyt. dalej AAN), Akta Prezydium Rady Ministrów (cyt. Akta PRM), t. 8, p. 1 (opracowanie archiwalne w maszynopisie); Dziennik Praw Królestwa Polskiego, nr. 1, poz. 1; Dziennik Praw RP nr 1, poz. 41, nr 15, poz. 226.

${ }^{3}$ R. Hausner, op. cit., s. 26; B. Hutten-Czapski, 60 lat życia politycznego i towarzyskiego, Warszawa 1936, t. 2, s. 517.

${ }^{4} \mathrm{~W}$ okresie funkcjonowania rządu Jędrzeja Moraczewskiego, przez krótki czas, na przełomie 1918 i 1919 r. w PRM istniało stanowisko ministra bez teki, zlikwidowane po ustapieniu tego gabinetu, J. Goclon, Rzad Jędrzeja Moraczewskiego 17 XI 1918 - 1611919 r., struktura, funkcjonowanie, dekrety, „Przegląd Nauk Historycznych”, R. VIII, nr 2, Łódź 2009, s. 99-137.

${ }^{5}$ M. Pietrzak, Rzady parlamentarne w Polsce w latach 1919-1926, Warszawa 1969, s. 203 i in.; J. Kuncewicz, Przebudowa. Rzecz o życiu i ustroju Polski, Kraków, b. r. wyd., s. 122 i in.; Z. Cybichowski, Polskie Prawo Państwowe, Warszawa 1925, t. 2, s. 176 i in.; P.A. Leszczyński, Centralna Administracja Wyznaniowa II RP. Ministerstwo Wyznań Religijnych i Oświecenia Publicznego, 
Podkreślenia wymaga fakt, iż rola premiera systematycznie wzrastała przez całe dwudziestolecie, co wiązało się ze wzrostem znaczenia organów, które jemu podlegały, lub okresowemu zmniejszaniu się znaczenia samej Rady Ministrów, której pracami kierował.

Należy dodać, że poza funkcją szefa gabinetu, premier w roku 1921 objął także funkcję przewodniczącego Komitetu Politycznego Ministrów, a w 1926 r. stanął na czele Komitetu Ekonomicznego Ministrów ${ }^{6}$.

Początkowo do „budżetu Prezydium Rady Ministrów wchodziły w roku 1918, oprócz centralnego zarządu, ponadto: Departament Stanu, Komisja Wojskowa, Drukarnie Państwowe, Monitor Polski i Komisja Urzędnicza. Departament Stanu przeorganizowano w roku 1918 na Ministerstwo Spraw Zagranicznych, z Komisji Wojskowej powstało w r. 1919 Ministerstwo Spraw Wojskowych", a agendy Komisji Urzędniczej, która szybko zakończyła swoją działalność przejął Wydział Personalny Rady Ministrów ${ }^{7}$.

Na przełomie 1918/19 r. PRM składało się z dwóch sekcji: administracyjnej i legislatywnej, z tym że przy tej drugiej istniała także Międzyministerialna Konsultacja Prawna ${ }^{8}$ oraz cztery wydziały: prasowy, osobowy, gospodarczy

Warszawa 2006, s. 121 i in.; idem, Konstytucyjna regulacja statusu Rady Ministrów w II Rzeczypospolitej, (w:) Prawo konstytucyjne II Rzeczypospolitej. Nauka i instytucje, red. P. Sarnecki, Kraków 2006, s. 222 i in.; E. Brodacka-Adamowicz, Ministrowie oświaty Drugiej Rzeczypospolitej. Okres rzqdów parlamentarnych (1918-1926), Siedlce 2010, s.16 i in. O współpracy parlamentu i rządu w zakresie „biegu prac ustawodawczych” i znaczenia w tych relacjach Prezydium Rady Ministrów dużo mówi pismo Ministra Zdrowia (z 30 czerwca 1920 r.) skierowane do Marszałka Sejmu Ustawodawczego, iż „ustawa o zdrojowiskach i uzdrowiskach opracowana przez Ministerstwo przesłana została do Prezydium Rady Ministrów", co wyraźnie ukazuje znaczenie tego organu również w zakresie prac projektodawczych, AAN, Akta PRM, t. 8, s. 2; sygn. 21941/598.

${ }^{6}$ Zob. Protokoły Komitetu Politycznego Rady Ministrów, wstęp, wybór, opracowanie M. Jabłonowski, W. Janowski, Warszawa-Pułtusk 2004, s. 6 i in.

${ }^{7}$ R. Hausner, op. cit., s. 26.

${ }^{8}$ Organ ten został utworzony 30 grudnia 1918 r. drogą uchwały rządu (przy Sekcji Legislatywnej Rady Ministrów), której skład stanowili przedstawiciele sekcji i wydziałów ustawodawczych i prawnych resortów. Rola tego organu nie była zbyt znacząca i jej działalność sprowadzała się głównie do uzgadniania tekstu poprawek, które zgłaszały poszczególne resorty, choć należy podkreślić, że nawet w samej instrukcji ustalonej dla tego organu (z początkiem 1919 r.) stwierdzono, że „Konsultacja ma na celu ustalenie zasad dla jednakowego rozstrzygania powstających w poszczególnych ministerstwach kwestii prawnych oraz dla ujednostajnienia techniki redakcyjnej projektów ustaw" oraz że „Konsultacja składa się z przedstawicieli Prezydium Rady Ministrów i wszystkich ministerstw, po jednym z każdego i obraduje na posiedzeniach pod przewodnictwem przedstawiciela Prezydium Rady Ministrów. Sprawy wymagające porozumienia niektórych Ministerstw mogą być rozpatrywane na posiedzeniach bez udziału przedstawicieli Ministerstw niezainteresowanych. Posiedzenia Konsultacji odbywają się w miarę potrzeby. Konsultacja wydaje opinie w kwestiach przytaczanych w art. 1 bądź na żądanie poszczególnych Ministerstw, bądź na wniosek jednego ze swych członków. Wszelkie czynności kancelaryjne Konsultacji załatwia Sekcja Legislacyjna Prezydium Rady Ministrów". Do jednych z bardziej istotnych spraw uzgodnionych przez tę Międzyministerialną Konsultację Prawną należał projekt „rozporządzenia Rady Ministrów w sprawie rozciągnięcia na ziemie przyłączone do obszaru RP na podstawie umowy o preliminaryjnym pokoju i rozejmie podpisanym w Rydze 12 października 1920 r., przepisów normujących meldowanie i zapi- 
i ogólny. W tym też okresie zostało utworzone Biuro Konstytucyjne (przy Prezydium), którego zadaniem miało być przygotowywanie i opracowywanie materiałów dla Komisji Konstytucyjnej Sejmu (z tym że biuro to zostało w połowie 1919 r. przeniesione do Biura Sejmu $)^{9}$.

W tym miejscu należy z całym naciskiem podkreślić, że Biuro Konstytucyjne Prezydium Rady Ministrów okazało się organem w dużo większym stopniu projektodawczym od sejmowej Komisji Konstytucyjnej! Na posiedzeniu rządu w dniu 18 lutego 1919 r., a więc już w okresie premierostwa Ignacego Paderewskiego, ustalono, iż „wobec tego, że Sejmowa Komisja Konstytucyjna zwróciła się do Rządu z zapytaniem, jaki charakter nosić ma zwołana przez Rząd Komisja Konstytucyjna, postanowiono wyjaśnić, że komisja ta nosić ma charakter ankiety i odroczyć jej ukonstytuowanie do chwili osiagnnięcia w tej sprawie porozumienia z Sejmową Komisją Konstytucyjną"10.

W okresie kierowania rządem przez Ignacego Paderewskiego (druga połowa 1919 r.) struktura Prezydium miała już trzy sekcje prezydialne: legislacyjna, prezydialną (z podziałem na Wydział personalny, Intendenturę i Rachubę), administracyjną (która dzieliła się na trzy wydziały: ekonomiczny, polityczny i kultury społecznej) oraz kancelarię ${ }^{11}$.

Struktura organizacyjna była wówczas jeszcze niezbyt ustabilizowana; dowodem na to może być fakt, iż w Prezydium nie obsługiwano spraw związa-

sywanie faktów ruchu naturalnego", czy zaakceptowana wspólnie opinia Departamentu Legislacyjnego w sprawie ,projektu ustawy o zmianie niektórych przepisów aktów stanu cywilnego”, a także projekt rozporządzenia rządu ,,W sprawie zmiany niektórych postanowień rozporządzenia Rady Ministrów z 18 października 1920 r. w sprawie organizacji statystyki ruchu naturalnego ludności", AAN, Akta PRM, t. 8, zał. 1; sygn. 1858/23.

${ }^{9}$ Na posiedzeniu Rady Ministrów w dniu 4 grudnia 1918 r. z inicjatywy premiera Jędrzeja Moraczewskiego podjęto decyzję o przygotowaniu projektu powołania Biura Konstytucyjnego, które ostatecznie utworzono w połowie stycznia 1919 r., którego głównym zadaniem miało być przygotowywanie materiałów dla prac Komisji Konstytucyjnej w Sejmie. W trakcie swojej działalności Biuro Konstytucyjne przygotowało kilka projektów konstytucyjnych, ale o bardzo zbliżonej do siebie treści, w czym uczestniczyli także profesorowie J. Buzek i M. Waliniak. Pracami Biura kierował Mieczysław Niedziałkowski, AAN, Akta PRM, t. 8, zał. 2; Protokoły Posiedzeń Prezydium Rady Ministrów, mf. 20048. p. 476; J. Goclon, op. cit., s. 115.

${ }^{10}$ Ankieta Konstytucyjna funkcjonowała do połowy 1919 r. i na posiedzeniach, którym przewodniczył prof. Michał Bobrzyński, analizowano materiały opracowane przez pracowników Biura Konstytucyjnego (zastępcą był prof. Zygmunt Chrzanowski, sekretarzem prof. Zygmunt Cybichowski). Na posiedzeniu Rady Ministrów w dniu 29 marca 1919 r. ,postanowiono wypracowany, przez zwołaną przez p. Prezydenta Ministrów ankietę, projekt konstytucji państwa przedłożyć Sejmowi nie jako projekt rządowy, a jako wynik ankiety”, ale nie zmienia to faktu, że większość prac na ustawą zasadniczą miała miejsce w Biurze Konstytucyjnym Prezydium Rady Ministrów (które zarządzeniem premiera z dnia 20 maja 1919 r., zostało ,przydzielone” do Biura Sejmu), AAN PRM, t. 8, zał. 2.

${ }^{11}$ Ibidem, t. 8, zał. 3. Zob.: J. Goclon, Rzad Ignacego Paderewskiego. Geneza, sktad osobowy $i$ działalność (16.01 - 9.12.1919), „Acta Universitatis Lodzienzis, Folia Historica” 86, 2011, s. 93-145. 
nych, z powołanym uchwałą rady Ministrów 1 sierpnia 1919 r., Komitetem Ekonomicznym Ministrów ${ }^{12}$.

W grudniu 1920 r. PRM, po powołaniu rządu Leopolda Skulskiego, ponownie składało się tylko z dwóch sekcji: administracyjnej i legislatywnej oraz dwóch wydziałów: organizacyjnego i prasowego.

Sekcja administracyjna dzieliła się na: sekretariat premiera (,,prezydialny”), Wydział ogólny i Wydział finansowo-gospodarczy. Sekretariat obsługiwał gabinet premiera, udzielał posłuchan, przyjmował memoriały, petycje, odbierał raporty, odpowiadał za stałą łączność z parlamentem oraz nadzorował przestrzeganie etykiety urzędowej w trakcie spotkań najwyższej rangi. Wydział ogólny zajmował się ogłaszaniem rozporządzeń i ustaw oraz sprawami rządu Komitetu Ekonomicznego Ministrów i Rady Obrony Państwa (w stosunkowo krótkim okresie jej funkcjonowania), sprawami personalnymi, społecznymi, politycznymi, sejmowymi, ekonomicznymi jednostek urzędowych przy PRM oraz sprawami gdańskimi. Wydział finansowo-gospodarczy dzielił się na: Dział finansowy, któremu podlegały sprawy budżetowe, rachunki i kasa, Referat osobowy, Kancelarię (prowadzącą dziennik podawczy i nadzorujący oddział ekspedycyjny i odział maszyn) oraz Dział gospodarczy, którego zakres

${ }^{12}$ Inicjatorem utworzenia Komitetu Ekonomicznego Ministrów był minister Skarbu Leon Biliński, który uważał, że taki organ przyczyni się do uzdrowienia systemu skarbowego państwa. Pierwsze posiedzenie odbyło się 30 sierpnia 1919 r., pod przewodnictwem L. Bilińskiego. Skład osobowy, regulamin pracy i zakres kompetencji rząd zatwierdził 19 lutego 1920 r. Skład Komitetu stanowili ministrowie: Skarbu, Spraw Zagranicznych, Spraw Wojskowych, Przemysłu i Handlu, Rolnictwa, Kolei Żelaznych, Robót Publicznych, Aprowizacji i Ministerstwa b. Dzielnicy Pruskiej, a także Generalny Komisarz Ziem Wschodnich. Pozostali ministrowie mogli uczestniczyć w tych posiedzeniach, na których rozpatrywane były sprawy ich resortów. Premier mógł zawsze uczestniczyć w posiedzeniach według własnej woli lub delegować swego reprezentanta. Zadaniem Komitetu było ustalanie zasad polityki ekonomicznej rządu, rozpatrywanie wszystkich wniosków o zmiany w prawie związanych z polityką gospodarczą oraz sprawy ekonomiczne wymagające uzgodnienia pomiędzy szefami resortów (wnioski te mogły zostać wniesione także na posiedzenie rządu, ale wcześniej musiały być rozpatrzone przez Komitet Ekonomiczny). Ponadto Komitet rozstrzygał w sprawach: umów o „zagranicznych dostawach rzędowych”, umów „eksportowych rządowych”, pożyczek rządowych dla spółek i towarzystw (w wysokości ponad 500 tys. marek), udzielania koncesji wywozowych i eksploatacyjnych oraz gwarancji rządowych; dalej: rozpatrywał i uchwalał zarządzenia i rozporządzenia mające duże znaczenie gospodarcze. W dniu 18 stycznia 1920 r. Komitet utworzył swój sekretariat generalny, którego zakres kompetencji obejmował: rozpatrywanie i przedkładanie przewodniczącemu Komitetu wniosków resortowych i przygotowywanie wniosków zbiorczych (po uzgodnieniu ich treści z właściwymi ministerstwami), nadzór nad prowadzeniem stenogramów posiedzeń i protokołów, sprawowanie kontroli nad wykonywaniem uchwał Komitetu oraz ustalanie zakresu kompetencji tych resortów, do których należały sprawy gospodarcze państwa. Regulamin KEM został zmieniony 21 lutego 1923 r., ale podstawowe ustalenia jego struktury i kompetencji pozostały w zasadzie te same. Zmiany zaszły w wyniku uchwały rządowej z dnia 29 października 1926 r., kiedy zadecydowano o przeniesieniu sekretariatu Komitetu do Prezydium Rady Ministrów; natomiast nowy statut PRM z 13 grudnia 1930 r. nie zawierał już wzmianki o istnieniu sekretariatu Komitetu Ekonomicznego Ministrów (wówczas uchwalono także kolejny regulamin KEM, obowiązujący do końca II RP), ibidem, t. 8, zał. 4. 
kompetencji obejmował dostawy i zamówienia, magazyny, nadzór nad gmachami rządowymi oraz sprawy środków lokomocji, a także aprowizacja urzędników i telefony. Sekcja legislatywna dzieliła się na Wydział Kodyfikacyjny i Wydział Konsultatywny; pierwszy zajmował się przygotowywaniem na posiedzenia rządu oraz uzgadnianiem i rozpatrywaniem na konferencjach międzyministerialnych, projektów i wniosków resortowych, które dotyczyły organizacji urzędów i stosunków urzędniczych; drugi zajmował się opracowywaniem aktów prawnych (ustaw i rozporządzeń), które miały normować organizację służby urzędniczej.

Jednym z donioślejszych projektów opracowanych przez PRM był projekt „O tymczasowym sprawowaniu władzy ustawodawczej i naczelnej władzy wykonawczej w Województwie Śląskim, z uzasadnieniem”, czy projekt Statutu Organizacji Ministerstwa Poczt. Ważną rolę odgrywało PRM również w sprawach opiniowania projektów ustaw nadsyłanych z poszczególnych resortów, jak na przykład projekt ustawy Ministerstwa Spraw Wojskowych „W przedmiocie poddania sądom doraźnym spraw o przestępstwa z chęci zysku, popełnione przez wojskowych". O roli PRM w procesie projektowania ustaw dobitnie świadczy rezolucja sejmowa uchwalona w lipcu 1920 r., która pilnie wzywała rząd, ażeby ,przedłożył Sejmowi projekt ustawy o reprezentacji wojskowej”. Wielokrotnie również poszczególne resorty zwracały się do PRM o różnego rodzaju interwencje, np. MSZ apelował do Prezydium, ,aby telegraficznie wywarło odpowiedni nacisk na Tymczasową Komisję Rządzącą w Cieszynie, celem natychmiastowego wstrzymania rugów mieszkaniowych i aby możliwie najszybciej powiadomiło MSZ, czy Tymczasowa Komisja Rządząca nie przekroczyła granic swoich kompetencji" (sprawa dotyczyła usuwania czeskich urzędników ze służbowych mieszkań w Cieszynie, które otrzymali od władz Austro-Węgier, jeszcze przed 1914 r.). O znaczeniu projektodawczej roli PRM może też wiele mówić przesyłanie do Sejmowej Komisji Konstytucyjnej własnych projektów ustaw, jak np. „w przedmiocie tymczasowej władzy ustawodawczej w Województwie Śląskim"13.

${ }^{13}$ W Sekcji legislacyjnej PRM opracowano m.in. również ważne (dla tak bardzo wówczas rolniczego kraju, jak Polska) projekty ustaw w dziedzinie melioracji; „o popieraniu robót melioracyjnych”, „o popieraniu przedsiębiorstw ulepszeń wodnych w interesie kultury krajowej” i „,o popieraniu przedsiębiorstw melioracyjnych przez państwa i ciała samorządowe drugiej instancji”. Sprawy te musiały być znacznej wagi skoro to PRM Sejm powierzył przygotowanie projektów ustaw wodnych, wzywając jednocześnie do przedłożenia , programu regulacji rzek niespławnych, zabudowań potoków górskich i melioracji pierwszorzędnych". Z Sejmu nadchodziły do PRM również pisma w sprawie wykonywania rezolucji sejmowych, jak np. „,w przedmiocie rejestracji rodzin, których żywiciele zostali przez bolszewików pomordowani, pomocy doraźnej dla takich rodzin i stałej pomocy dla osób cywilnych poszkodowanych wskutek działań wojennych". PRM opracowywało również takie pisma, jak np. „Motywy do projektu Rozporządzenia Rady Obrony Państwa o budowie linii kolejowej Kokoszki - Mały Kock lub Kokoszki - Gdynia" (która miała omijać Gdańsk), ibidem, sygn. 1941/22, 4766/21, 7649/21, 24163/21, 1941/22, 5645/21, 2400/22 t. 8, zał. 5. 
Wydział organizacyjny był organem pomocniczym premiera, który ułatwiał mu nadzór nad przebiegiem procesu organizacji wszystkich naczelnych urzędów. Wydział prasowy zajmował się sprawami oświadczeń rządowych i kontaktami z dziennikarzami.

Poza tym funkcjonowały jeszcze dodatkowe komórki:

a/ Biuro Plebiscytowe ${ }^{14}$,

b/ referat gdański ${ }^{15}$,

c/ biuro nadzwyczajnych Komisji oszczędnościowych ${ }^{16}$,

d/ delegat PRM, do spraw m.in. ,zdobyczy wojennych" ${ }^{17}$.

${ }^{14}$ Biuro Plebiscytowe (nazywane też referatem plebiscytowym) było komórką organizacyjną utworzoną jedynie czasowo, tj. do załatwienia konkretnych spraw, związanych z prowadzonymi akcjami plebiscytowymi i jego działalność była pomocnicza wobec Komisji do spraw likwidacji Komitetów plebiscytowych na Spiszu i Orawie, w Cieszynie, Kwidzynie i Olsztynie (utworzoną 29 lipca 1920 r. uchwałą Rady Ministrów, której skład stanowili reprezentanci PRM, Ministerstwa Spraw Zagranicznych, Wewnętrznych, Wojskowych i Skarbu). Zakres kompetencji Biura plebiscytowego uległ poszerzeniu po przekazaniu PRM spraw poza wojskowych przez Wydział Plebiscytowy Górnego Śląska przy oddziale II Sztabu Generalnego (zlikwidowany 11 stycznia 1922 r.). Działalność Biura Plebiscytowego, utworzonego w 1920 r., trwała do 1924 r. Ibidem, t. 8, zał. 6.

15 „Sprawy gdańskie”, tj. sprawy Komisarza Generalnego RP w Wolnym Mieście Gdańsku, początkowo podlegały w całości Prezydium Rady Ministrów (o czym wyraźnie mówiła instrukcja służbowa z 31 maja 1920 r. odnosząca się do kwestii załatwiania spraw gdańskich przez urzędników), jednak już na posiedzeniu rządu 6 września 1920 r. uchwalono wyłączenie „,spraw natury dyplomatycznej” z referatu gdańskiego PRM, polecając, aby w sprawach dyplomatycznych Komisarz Generalny kontaktował się wyłącznie z polskim Ministerstwem Spraw Zagranicznych. Natomiast sprawy związane z korzystaniem z portu w Gdańsku przekazano, uchwałą rządu z 12 kwietnia 1922 r., Ministerstwu Przemysłu i Handlu. Referat gdański uległ likwidacji decyzją uchwały rządowej z 21 lutego 1923 r. i wszystkie sprawy gdańskie przeszły do Ministerstwa Spraw Zagranicznych, ibidem, t. 8, zał. 7.

${ }^{16} \mathrm{~W}$ dniu 29 lipca 1920 r. rozporządzeniem premiera utworzono Komisję do spraw oszczędności państwowych, co było wynikiem rezolucji sejmowej z 16 lipca tegoż roku, która wzywała rząd do wprowadzenia w całej administracji państwa możliwie największych oszczędności; wiązało się to niewątpliwie z gwałtownymi wydatkami wojennymi, w wyniku narastającego lawinowo zagrożenia ze strony nacierającej w kierunku Warszawy Armii Czerwonej. W rezolucji sejmowej polecono wstrzymanie wszystkich wydatków, które nie wiązały się z obroną Rzeczypospolitej, natomiast do zakresu powołanej Komisji należało: redukcja stanowisk urzędniczych, opracowanie metod uproszczenia administracji państwowej i zwiększenie sprawności działania wszystkich urzędów. Podobną Komisję organizacyjno-oszczędnościową pod przewodnictwem premiera, powołano 28 grudnia 1922 r. W dniu 26 marca 1923 r. uchwałą rządu zastąpiono tę Komisję instytucją Nadzwyczajnego Komisarza Oszczędnościowego przy premierze, którąjednak zlikwidowano już w końcu 1925 r. i na posiedzeniu rządu w dniu 16 grudnia 1925 r. postanowiono utworzyć trzyosobową Komisję reorganizacji biurowości, której działalność dzieliła się na: a) projekty instrukcji biurowej dla władz I, II i III instancji oraz b) projekty: kompilacji obowiązujących przepisów i trybu urzędowania organów administracji (działalność zakończyła się w 1929 r.). Zadania reorganizacji administracji kontynuowała, powołana w 1928 r., Komisja dla usprawnienia Administracji Publicznej, ibidem, t. 8, zał. 8.

${ }^{17}$ W dniu 18 lipca 1919 r. rząd przekazał wszelkie sprawy ,zdobyczy wojennej” (dotyczyło to mienia przejmowanego od niemieckich i austriackich wojsk okupacyjnych) Komisarzowi Generalnemu Ziem Wschodnich, który na mocy otrzymanych pełnomocnictw rządowych ustanowił w dniu 25 lipca 1919 r. Urząd Zdobyczy Wojennej, przy reprezentancie Komisarza Generalnego w Warszawie. Należy dodać, że w dniu 17 października 1919 r. Naczelny Wódz Józef Piłsudski powołał swoim dekretem (jednocześnie jako Naczelnik Państwa) Komisję Śledczą do zbadania stawianych zarzutów zarówno 


\section{Od roku 1920 istnieją jeszcze instytucje autonomiczne (obok Zarządu Cen- tralnego PRM):}

1. Prokuratoria Generalna RP,

2. Polska Agencja Telegraficzna,

3. Zarząd Drukarni Państwowych,

4. Monitor Polski,

5. Urząd Propagandy Wewnętrznej ${ }^{18}$,

6. Urząd Propagandy Zagranicznej ${ }^{19}$,

7. Kancelaria Rady Obrony Państwa ${ }^{20}$,

wobec oficerów, jak i urzędników cywilnych, odnośnie do zdobyczy wojennej na froncie wschodnim, gdzie od lutego 1919 r. trwała niewypowiedziana wojna polsko-rosyjska, ibidem, t. 8, zał. 9.

${ }^{18}$ Biuro propagandy wewnętrznej istniało stosunkowo krótko, bo od 5 sierpnia 1920 (uchwała rządu) do 1 grudnia tegoż roku i zostało powołane dla „budzenia ducha patriotycznego, zwalczania defetyzmu w narodzie i uświadomienia konieczności czynnej pomocy dla państwa w walce z wrogiem". W wyniku w/w uchwały Rady Ministrów z 5 sierpnia 1920 r. dotychczasowe biura propagandy przy Ministerstwie Spraw Wojskowych przekazano do PRM, tj. do Biura Propagandy Wewnętrznej, które swoim zasięgiem objeło cały kraj z delegatami wojewódzkimi, „lotnymi” instruktorami organizacji i powiatowymi „mężami zaufania”. Biuro to prowadziło własny dziennik podawczy, posiadało własną kancelarię i używało odrębnych pieczęci (ale na użytek wewnętrzny, np. pieczęcie wpływu, o treści: „Prezydium Rady Ministrów. Biuro Propagandy Wewnętrznej”) i stosowało własne nadruki na aktach spraw. Postawione w stan likwidacji na posiedzeniu gabinetu w dniu 3 listopada 1920 r. (z uzasadnieniem premiera, że „niebezpieczeństwo minęło, a urząd spełnił swoją rolę"), z wejściem w życie tej decyzji z dniem 1 grudnia tegoż roku, faktycznie zakończyło swoją działalność w maju 1921 r., ibidem, t. 8, zał. 10.

${ }^{19}$ Biuro Propagandy Zagranicznej powstało w szczególnej sytuacji polityczno-militarnej, w jakiej znalazła się Rzeczpospolita w sierpniu 1920 r. Jednostkę tę utworzono 25 sierpnia tegoż roku, lecz nie uchwałą rządu, jak w/w biura, a rozporządzeniem Rady Obrony Państwa, ale jako organ przy Prezydium Rady Ministrów. Głównym zadaniem tego biura miało być „pozyskanie poparcia zagranicą akcji pokojowej Rządu Polskiego" (jego działalność przewidywano na okres sześciu miesięcy). Strukturę tego organu stanowily: centrala z szefem biura i jego zastępca oraz referenci: instrukcji politycznej, telegraficznej obsługi delegatów zagranicznych, obsługi korespondentów pism obcych, propagandy wydawniczej (w tym literackiej, artystycznej i prasowej), dalej: kancelaria, thumacze, buchalter i archiwum; poza tym biuro to miało stałych delegatów w: Paryżu, Londynie, Rzymie, Nowym Jorku, Bernie i Brukseli oraz delegatów specjalnych (wyjeżdżających w misjach okresowych) w: Wiedniu, Berlinie, Sztokholmie, Amsterdamie, Bukareszcie, Rydze, Zagrzebiu i przy Lidze Narodów. Biuro uległo likwidacji w połowie 1921 r., a sprawy działu informacji dla korespondentów zagranicznych przejęło MSZ, zaś bibliotekę, filmy, zdjęcia, inwentarz i akta - Prezydium Rady Ministrów, natomiast rysunki i akwaforty - Ministerstwo Sztuki i Kultury, ibidem, t. 8, zał.11.

${ }^{20}$ Kancelaryjnie Radę Obrony Państwa obsługiwała kancelaria Prezydium Rady Ministrów. W dniu utworzenia Rady Obrony Państwa (1 lipca 1920 r.) na swoim pierwszym posiedzeniu określiła swoje cele i zakres kompetencji jako: pracę nad podniesieniem „ducha w narodzie i wojsku”, załatwianie spraw wymagających szybkiego rozstrzygnięcia, czego nie można było uzyskać zwykłą drogą ustawodawcza, decydowanie w działaniach wojennych o politycznym znaczeniu, a także do kompetencji Rady należało decydowanie o pokoju i sprawach związanych z jego zawieraniem, ibidem, t. 8, zał. 12. Rada Obrony Państwa była zupełnie nowym organem i sytuowała się (ze względu na swój skład personalny) pomiędzy rządem a parlamentem - w pewnym zakresie posiadając uprawnienia obydwóch tych instytucji, a przede wszystkim uprawnienie ustawodawcze w postaci możliwości wydawania zarządzeń i rozporządzeń, i to z klauzulą natychmiastowej wykonalności. Nie oznaczało to jednak, że nie istniały żadne ograniczenia tych prerogatyw; Rada otrzymała możli- 


\section{Ministerstwo bez teki,}

9. Departament dla spraw polskich do ziem wschodnich (Litewsko-Białoruski) $^{21}$

10. Główny Urząd Statystyczny (został odłączony od PRM mocą ustawy z 1 czerwca 1923 r.),

11. Państwowy Urząd do Spraw Powrotu Jeńców, Uchodźców i Robotników (odłączony od PRM mocą ustawy z 4 listopada 1920 r.).

Prezydium Rady Ministrów staje się bardziej organizacyjnie rozbudowaną instytucją w końcu 1920 r. (dokładnie 20 grudnia 1920 r. na 119. posiedzeniu Rady Ministrów przyjęto nową strukturę organizacyjną PRM); zastąpiono wówczas sekcje departamentami, wprowadzając: departament prezydialny (w miejsce sekcji administracyjnej) i legislatywny oraz trzy wy-

wość wydawania rozporządzeń i zarządzeń wyłącznie w sprawach „związanych z prowadzeniem i zakończeniem wojny oraz zawarciem pokoju. Poza tym rozporządzenia i zarządzenia, które w myśl ustaw wymagały uchwały Sejmu, winny być następnie na najbliższym posiedzeniu Sejmu składane za pośrednictwem Prezydenta Ministrów Sejmowi do zatwierdzenia”. W myśl tych przepisów nie można wnioskować, że Rada przejęła całkowitą władzę w państwie, wydając wprawdzie aż ok. 90 aktów prawnych, ale wszystkie nie przekroczyły granic kompetencji Rady, ustalonych w ustawie lipcowej, i wszystkie wymagały - dla swojej ważności - potwierdzenia Sejmu. Rada nie była „rządem", lecz dzięki niej było możliwe skoordynowanie wszystkich funkcji państwowych z działalnością gospodarczą i z pracą sztabu generalnego. Ustawa sejmowa zakreślała kompetencje Rady bardzo szeroko: były to wspomniane już wszystkie sprawy dotyczące prowadzenia i zakończenia wojny, zawarcia pokoju oraz wydawanie w tych sprawach zarządzeń i rozporządzeń, które podlegały natychmiastowemu wykonaniu. Rozporządzenia wymagające zrealizowania przez Sejm musiały być na jego najbliższym posiedzeniu zatwierdzone. Tak więc cały system stanowienia prawa przez Sejm nie został zatrzymany, lecz ograniczony, ponieważ Rada otrzymała prawo wydawania decyzji i wymuszania szybkiego działania na organach państwowych. To Rada, dysponując ogromnym kapitałem zaufania polskiego narodu, umożliwiła powołanie tak znacznej armii, a swoimi zarządzeniami usprawniła produkcję przemysłową, zapobiegając jednocześnie rozprzężeniu gospodarczemu. Nie naruszając podstaw ustroju Rzeczypospolitej mogła interweniować na każdym etapie życia państwowego, lecz często sprowadzało się to jedynie do wytykania błędów, czy wydawania odezw do ludności, w obliczu śmiertelnego zagrożenia nastąpiła bowiem wyjątkowa konsolidacja większości narodu, wokół ówczesnych przywódców politycznych i wojskowych, wśród których niewątpliwy prym wiódł Naczelny Wódz J. Piłsudski, P. M. Marszałek, Rada Obrony Państwa z 1920 roku. Studium prawno-historyczne, Wrocław 1995, s. 175, 176; J. Goclon, W obronie Europy. Wojna z bolszewicka Rosja w 1920 roku, Wrocław 2009, s. 102-106; idem, Rzad Władysława Grabskiego (23 VI-24 VII 1920 r.), skład, działalność i pozycja wobec Rady Obrony Państwa, (w:) „Klio. Czasopismo poświęcone dziejom Polski i powszechnym", Toruń 2011, nr 18(3), s. 84-87; P. Zaremba, Historia Dwudziestolecia 1918-1939, Paryż 1981, t. 1, s. 190-192; Ustawa o utworzeniu Rady Obrony Państwa z dnia 1 lipca 1920 r., Dziennik Ustaw Rzeczypospolitej Polskiej, nr 53, poz. 327. Wg A. Ajnenkiela, ROP przejęła pełnię władzy w kraju (podobnie A. Leinwand), ale na podstawie analizy zachowanych źródeł (w tym aktów prawnych), trudno się z tym zgodzić. Por.: A. Ajnenkiel, Historia sejmu polskiego, Warszawa 1989, t. II, cz. 2, s. 41 i in.; idem, Polskie konstytucje, Warszawa 1982, s. 232; A. Leinwand, Polska Partia Socjalistyczna wobec wojny polsko-radzieckiej 1919-1920, Warszawa 1964, s. 169.

${ }^{21}$ W 1919 r. istniał stosunkowo krótko Departament Litewsko-Białoruski, określany także departamentem dla spraw polskich ziem wschodnich, który jednak już w następnym roku nie figurował w wykazie budżetowym Prezydium Rady Ministrów, AAN, PRM, t. 8, zał. 13. 
działy: polityczno-prasowy, wydział dla specjalnych zleceń oraz wydział organizacyjny $^{22}$.

Należy dodać, że ta struktura ustrojowa PRM została ustalona na podstawie rozporządzenia rządu z 20 października1920 r. „,W sprawie organizacji i zasad urzędowania ministerstw" i odtąd ministerstwa miały dzielić się na departamenty i wydziały. Ustrój PRM przyjęty na posiedzeniu rządu 20 grudnia 1920 r. został powtórnie zatwierdzony w rozporządzeniu Rady Ministrów (18 marca1921 r.) i wówczas wprowadzono w życie oficjalny (po raz pierwszy) statut PRM (niewielkie zmiany dotyczyły departamentu prezydialnego, ponadto akt ten nie przewidywał już wydziału dla specjalnych zleceń $)^{23}$.

Ponowne zmiany nastąpiły w okresie działalności rządu Antoniego Ponikowskiego, kiedy to droga uchwały rządu (3 listopada 1921 r.) utworzono w PRM trzy departamenty: polityczny, prezydialny i legislatywny ${ }^{24}$.

W dniu 19 sierpnia 1922 r. została wprowadzona kolejna nowa struktura Prezydium Rady Ministrów i podział na cztery wydziały: administracyjny, finansowo-gospodarczy, personalno-organizacyjny, polityczno-prasowy oraz kancelarię. Spośród departamentów zachowano jedynie departament legislatywny, z podziałem na dwa referaty: kodyfikacyjny i wniosków prawodaw$\mathrm{czych}^{25}$. Pozostał sekretariat Komitetu Politycznego i referat orderowy ${ }^{26}$.

${ }^{22}$ Dowodem znaczenia Departamentu Legislatywnego może być fakt, iż w 1923 r. to ten departament przedkładał ,w porozumieniu z Ministerstwem Sprawiedliwości i Ministerstwem Spraw Wewnętrznych [...] Radzie ministrów odpowiednie wnioski o poddanie Głównego Urzędu Statystycznego pod władzę MSW (jako departament tego resortu), ibidem, sygn. 2637/23; t. 8, zał. 14.

${ }^{23}$ Ibidem, t. 8, p. 6, zał. 14.

${ }^{24}$ Miesiąc wcześniej (6.10.1921 r.) powołano Komitet Polityczny Ministrów (na czele z premierem), co wiązało się z utworzeniem nowej jednostki organizacyjnej w PRM (lecz jej działalność uwidoczniła się dopiero w 1922 r.). Komitet ten utworzono uchwałą rządową w dniu 6 października 1921 r., którego zadaniem miało być „opracowanie wytycznych polityki zagranicznej i wewnętrznej”; na tym samym posiedzeniu rządu uchwalono regulamin tego Komitetu, który ustalał skład tego organu i tryb jego działania i w którym ustalono, że jednostkę tę stanowią: premier, jako przewodniczący, szefowie resortów: MSZ, MSW, Skarbu i dodatkowo jeden z ministrów, wybrany przez gabinet - jako członkowie stali, w posiedzeniach mogli bowiem uczestniczyć także szefowie tych resortów, którzy nie byli członkami stałymi, ale sprawy dotyczyły ministerstw, którymi kierowali. Zadaniem tego Komitetu było opracowywanie zasad polityki zagranicznej i wewnętrznej rządu. Wszelkie sprawy na posiedzenia tego organu wnosił premier $\mathrm{z}$ inicjatywy własnej lub na wniosek jednego z ministrów; premier mógł każdy z takich wniosków poddać najpierw pod głosowanie tego Komitetu. Nieobecnego premiera zastępował jeden ze stałych członków - minister wskazany przez szefa gabinetu. Komitet miał prawo tworzyć osobne sekcje „dla spraw pierwszorzędnego znaczenia państwowego lub spraw wymagających w danej chwili specjalnej uwagi rządu" (uchwała rządu z 25 marca 1925 r.; utworzono sekcje: dla spraw mniejszości narodowych oraz dla spraw województw wschodnich). Z zachowanych akt wynika, że po 1926 r. Komitet Polityczny Rady Ministrów zaprzestał swojej działalności, ibidem, zał. 15, 16, 17; O Niepodległa i granice. Protokoły Komitetu Ekonomicznego Rady Ministrów 1921-1926, Warszawa-Pułtusk 2004, s. 7, 14 i in.

${ }^{25} \mathrm{~W}$ dniu 29 lipca $1920 \mathrm{r}$. rozporządzeniem premiera utworzono Komisję do spraw oszczędności państwowych, co było wynikiem rezolucji sejmowej z 16 lipca tegoż roku, która wzywała rząd do wprowadzenia w całej administracji państwa możliwie największych oszczędności; wiązało się to niewątpliwie z gwałtownymi wydatkami wojennymi, w wyniku narastającego lawinowo zagrożenia ze 
W dniu 28 września rząd uchwałą zniósł zupełnie podział PRM na departamenty i wprowadził nowy podział na pięć wydziałów: administracyjny, personalno-organizacyjny, polityczno-prasowy, finansowo-gospodarczy i nowy wydział (wobec stanu z 19 sierpnia 1922 r.) - prawny; pozostawiono także kancelarię. Zmiany te wprowadził premier Julian Nowak ${ }^{27}$. Należy podkreślić, że wprowadzona wówczas struktura PRM, z niewielkimi zmianami zatwierdzona rozporządzeniem Rady Ministrów (13 marca 1925 r.; M.P. nr 62), utrzymała się niezmieniona do 28 sierpnia $1926 \mathrm{r}^{28}$

Drugi okres funkcjonowania PRM to czas od 28 sierpnia 1926 r. do 12 września $1930 \mathrm{r}$. W dniu 16 czerwca (na swoim 45. posiedzeniu) rząd uchwalił zasadniczą reorganizację PRM, co miało przynieść pewne oszczędności; deficyt w styczniu 1926 r. sięgał $220 \mathrm{mln}$ złotych i miał być wyrównany poprzez reformę administracji państwowej i ,podniesienie dochodowości przedsiębiorstw państwowych". W tej sytuacji w PRM utworzono specjalny referat do „udoskonalenia administracji”, a następnie Komisję Usprawnienia Administracji Publicznej przy premierze ${ }^{29}$.

W dniu 28 sierpnia 1926 r. opublikowano rozporządzenie rządu, którym anulowano statut Prezydium Rady Ministrów z 13 marca 1925 r., wprowadzając w nowym statucie jednostki organizacyjne w PRM, tj. Gabinet Prezesa Rady Ministrów i Biuro Prezesa Rady Ministrów. Dodatkowym uzupełnieniem nowego statutu było rozporządzenie rządu (z 23 marca 1927 r.), którym utworzono Biuro Prawne (chociaż należy zaznaczyć, że już wcześniej funkcjonowała niewielka komórka prawna w PRM i to pomimo formalnego skierowania jej do likwidacji - po powołaniu Rady Prawniczej przy Ministrze Sprawiedliwości) ${ }^{30}$.

strony nacierającej w kierunku Warszawy Armii Czerwonej. W rezolucji sejmowej polecono wstrzymanie wszystkich wydatków, które nie wiązały się z obroną Rzeczypospolitej, natomiast do zakresu powołanej Komisji należało: redukcja stanowisk urzędniczych, opracowanie metod uproszczenia administracji państwowej i zwiększenie sprawności działania wszystkich urzędów. Podobną Komisję organizacyjno-oszczędnościową pod przewodnictwem premiera, powołano 28 grudnia $1922 \mathrm{r}$. W dniu 26 marca 1923 r. uchwałą rządu zastapiono tę Komisję instytucją Nadzwyczajnego Komisarza Oszczędnościowego przy premierze, który jednak zlikwidowano już w końcu 1925 r. i na posiedzeniu rządu w dniu 16 grudnia 1925 r. postanowiono utworzyć trzyosobową Komisję reorganizacji biurowości, której działalność dzieliła się na: a) projekty instrukcji biurowej dla władz I, II i III instancji oraz b) projekty: kompilacji obowiązujących przepisów i trybu urzędowania organów administracji (działalność zakończyła się w 1929 r.). Zadania reorganizacji administracji kontynuowała, powołana w 1928 r., Komisja dla usprawnienia Administracji Publicznej, AAN, akta PRM, t. 8, zał. 8, 18.

${ }^{26}$ Referat orderowy PRM zajmował się sprawami odznaczeń, w oparciu o ustawę z 4 lutego 1921 r. o ustanowieniu orderu „Orła Białego”, orderu „Odrodzenia Polski” i in., którego sekretariat gromadził akta dotyczące spraw orderowych i odznaczeń oraz zajmował się sprawami kapituł orderowych, ibidem, t. 8, zał. 19 .

${ }^{27}$ Ibidem, t. 8, p. 7, zał. 20.

${ }^{28}$ Ibidem, zał. 21, statut z 1925 r. to drugi oficjalny statut PRM, którym ulepszono organizację Prezydium.

${ }^{29}$ Ibidem, p. 7; R. Hausner, Poczynania organizacyjno-oszczędnościowe, s. 156.

${ }^{30}$ Ibidem, zał. 22. 
Należy podkreślić, że struktura Prezydium w latach 1926-1930 znacznie różniła się od struktury resortów, ponieważ wobec PRM nie miało zastosowania rozporządzenie z 25 sierpnia 1926 r., w sprawie zasad organizacji i urzędowania ministerstw (które uchyliło rozporządzenie z 20 października 1920 r.) o podziale resortów na departamenty, a te na wydziały. Zmiany wprowadzone w strukturze PRM w sierpniu 1926 r. miały na celu zwiększenie łączności pomiędzy premierem a poszczególnymi resortami i w dziedzinie ogólnej polityki rządu wzmocnienie jego inicjatywy jako całości. $Z$ tych powodów w PRM wprowadzono (w miejsce dotychczasowych pięciu wydziałów) podział na dwie jednostki: Gabinet Prezesa Rady Ministrów (jego zadaniem miało być utrzymywanie łączności z poszczególnymi ministerstwami i przedstawianie premierowi spraw, które miały być wprowadzane przez niego pod obrady rządu) oraz Biuro Prezesa Rady Ministrów (obejmujący aparat wykonawczy tego urzędu) ${ }^{31}$.

Podkreślenia wymaga fakt, że zintensyfikowanie inicjatyw ustawodawczych Rady Ministrów wzmogło prace komórki prawnej PRM, która od początku II Rzeczypospolitej - czy to pod nazwą Departamentu Legislatywnego, później Wydziału Prawnego, następnie Radców Prawnych przy Prezesie Rady Ministrów, a następnie Biura Prawnego - funkcjonowała głównie dla przedkładania rządowi lub premierowi opinii prawnych odnośnie do projektów ustawodawczych ${ }^{32}$.

Trzeci okres działalności PRM przypadł na czas od 12 grudnia 1930 r. do września $1939 \mathrm{r}$.

W omawianym okresie podstawą organizacji PRM było rozporządzenie rządu z 12 grudnia 1930 r., w którym ogłoszono nowy statut Prezydium Rady Ministrów. Zgodnie z nim zniesiono podział na gabinet premiera, jako komórki informacyjnej i pozostałych biur (jako organów wykonawczych), wprowadzając ujednolicenie wszystkich biur, które stały się komórkami zarówno informacyjnymi, jak i wykonawczymi Prezesa Rady Ministrów. W tym okresie biura były podstawowymi jednostkami organizacyjnymi w PRM.

Wspomniane rozporządzenie z $1930 \mathrm{r}$. wprowadzało podział PRM na cztery biura: Biuro Prezydialne Prezesa Rady Ministrów, Biuro Prawne Prezesa Rady Ministrów, Biuro Ekonomiczne Prezesa Rady Ministrów i Biuro Usprawnienia Administracji Prezesa Rady Ministrów. Nie był to jednak podział stały i w latach 1930-1939 podział PRM został rozszerzony na osiem jednostek; były to: Biuro Prezydialne, Biuro Prawne, Biuro Ekonomiczne, Biuro Usprawnienia Administracji, Biuro Personalne, Biuro Zadań Specjalnych, Biuro Polityki Narodowościowej, Biuro Akcji Planowania. Z tym że Biuro Za-

${ }^{31}$ Gabinet premiera otrzymał jako jedno z pierwszych zleceń zbadanie nowych zjawisk gospodarczych w Polsce, co zaowocowało jesienią 1926 r. powołaniem Komisji Opiniodawczych przy Prezesie Komitetu Ekonomicznego oraz utworzenia Komisji Ankietowej do badania kosztów produkcji i wymiany, Materiały odnoszące się do działalności Rządu, Warszawa 1928.

${ }^{32}$ Ibidem. 
dań Specjalnych i Biuro Polityki Narodowościowej należały do komórek nadzwyczajnych PRM i ich dyrektorów określano mianem urzędników do zadań specjalnych $^{33}$.

Do zadań Biura Prezydialnego Prezesa Rady Ministrów należały: „sprawy parlamentarne wynikające ze stosunku rządu do ciał ustawodawczych, sprawy związane z ustaleniem porządków dziennych posiedzeń Rady Ministrów, sprawy orderowe, ceremoniału urzędowego i posłuchań u Prezesa Rady Ministrów oraz sprawy prasowe" 34 . Poza tym jednostce tej podlegały także sprawy, personalne, gospodarcze, budżetowe, rachunkowo-kasowe oraz sprawy, które nie zostały przekazane pozostałym komórkom PRM. Biuro Prezydialne załatwiało również sprawy budżetowe, kontrolę i nadzór nad gospodarką urzędów oraz zakładów, które podlegały premierowi, a także sprawowało nadzór polityczny nad działalnością Polskiej Agencji Telegraficznej i nad państwowymi wydawnictwami. Skład Biura Prezydialnego stanowiły: sekretariat premiera, sekretariat rządu, referat spraw parlamentarnych oraz referat etykiet i orderowy. Ponadto funkcjonowała wspólna kancelaria dla wszystkich komórek, wydział (lub referat) budżetowo-gospodarczy, wydział prasowy, archiwum i biblioteka (w niektórych okresach Wydział Budżetowo-gospodarczy oraz Wydział Prasowy - występowały samodzielnie) $)^{35}$.

Biuro Prawne obejmowało następujące sprawy: opracowywanie projektów ustaw i rozporządzeń zleconych przez rząd, opracowywanie projektów ustaw i rozporządzeń (na zlecenie premiera) nienależących do kompetencji poszczególnych ministerstw, rozpatrywanie i opiniowanie (w aspekcie prawnym) projektów ustaw, dekretów i rozporządzeń, z jednoczesnym ustaleniem ostatecznej redakcji, czy obsługę związaną z ogłaszaniem ustaw i dekretów w Dzienniku Ustaw RP, a także rozporządzeń, zarządzeń i obwieszczeń naczelnych władz w „Monitorze Polskim”. Biuro to zajmowało się opracowywaniem projektów aktów prawnych konstytucyjnych i dla premiera przygotowywało różnego rodzaju materiały dla działalności legislacyjnej rządu. Jego zadaniem było także referowanie spraw przedkładanych przez premiera na posiedzeniach rządu oraz wydawanie opinii i prowadzenie wykazów wniosków ustawodawczych. Należy podkreślić, że Biuro Prawne nie tylko opiniowało, ale często rozstrzygało różne kwestie prawne na wniosek zarówno resortów, jak i innych komórek PRM. Można powiedzieć, że Biuro Prawne pełniło rolę ,pogotowia prawnego” i to na równi z resortem sprawiedliwości (!), dla wszelkich potrzeb aparatu Rady Ministrów. Podział PRM według stanu na 15 grudnia 1930 r. był następujący:

1. Referat resortów: Przemysłu i Handlu, Skarbu, Robót Publicznych, Poczt i Telegrafów, Spraw Wojskowych oraz sprawy urzędnicze;

${ }^{33}$ Oprócz dyrektorów Lepeckiego i Paprockiego był jeszcze trzeci urzędnik do zleceń specjalnych, mjr Jerzy Krzymuski, AAN, Akta PRM, t. 8, p. 8-9, zał. 23, 24.

${ }^{34}$ Ibidem, p. 10.

${ }^{35}$ Ibidem. 
2. Referat resortów: Rolnictwa, Reform Rolnych, Pracy i Opieki Społecznej;

3. Referat resortów: Sprawiedliwości, Spraw Zagranicznych, Wyznań Religijnych i Oświecenia ${ }^{36}$.

Procedura rozpatrywania projektów aktów prawnych przesyłanych do opinii Biura Prawnego PRM była następująca: wszelkie projekty (ustaw, rozporządzeń czy zarządzeń prezydenta oraz uchwał i rozporządzeń rządu) były przesyłane (w 25 egz.) do Biura Prawnego PRM, dla umieszczenia ,w porządku dziennym" obrad Rady Ministrów. Do tekstu projektu musiał być dołączony jeden egzemplarz pisma „towarzyszącego”, z podpisem właściwego ministra, w którym obowiązkowo musiano podać, czy projekt jest uzgodniony merytorycznie, czy też istniejąjakieś sprawy sporne (dotyczące np. techniki legislacyjnej), co rozpatrywało Biuro Prawne PRM. W sytuacji, kiedy dany projekt nie był uzgodniony z innymi resortami, to obowiązkowo umieszczano w jego tekście wszelkie zmiany, jakie proponowały poszczególne resorty, których projekt także dotyczył. Następnie projekt, który został uchwalony przez rząd, był przekazywany do Wydziału Prawnego danego ministerstwa, a stamtąd (w 5 egz.) wysyłany do Marszałka Sejmu, w celu poddania pod obrady Sejmu (odpis wysłanego projektu do parlamentu otrzymywało PRM) ${ }^{37}$.

Działalność projektodawcza Biura Prawnego (które faktycznie przejęło sprawy dawnego Departamentu legislatywnego) ukazuje, jak dużą rolę w dziedzinie nieformalnej inicjatywy ustawodawczej odegrała ta jednostka administracyjna PRM. Przykładem mogą być tutaj pisma przesyłane (szczególnie w pierwszej połowie lat dwudziestych) wprost z poszczególnych resortów do PRM w celu opracowania (lub zaopiniowania) projektu danej ustawy; i tak, Ministerstwo Sprawiedliwości zwróciło się o „,przysłanie projektu ustawy w przedmiocie orzecznictwa karno-administracyjnego" (1921 r.) czy o konsultację prawną, „W przedmiocie zmian $\mathrm{w}$ kwotach pieniężnych określonych w przepisach karnych i karno-skarbowych". Kolejnym przykładem może być wniosek Ministerstwa Rolnictwa do PRM o zaopiniowanie projektu ustawy „W przedmiocie zmiany granic oraz rozwiązywania i tworzenia gmin wiejskich na obszarze b. zaborów rosyjskiego i austriackiego"38.

\footnotetext{
${ }^{36}$ Ibidem, p. 10, 11.

${ }^{37}$ P.A.Leszczyński, Centralna administracja, s. 175.
}

${ }^{38}$ Do PRM zwracały się o sporządzenie projektu danego aktu prawnego nie tylko resorty, ale również inne instytucje centralne, jak np. Główny Urząd Statystyczny, który wnioskował o przygotowanie projektu rozporządzenia rządu „w sprawie powszechnego spisu ludności”, czy projektu rozporządzenia „W sprawie spisu gospodarstw rolnych i leśnych ponad 50 ha wraz z kwestionariuszem i instrukcją", a także projektu rozporządzenia rządu ,w sprawie statystyki ruchu naturalnego ludności wraz z kwestionariuszem" i projektu „,w sprawie stanu zatrudnienia w przemyśle wraz z kwestionariuszem”. W PRM przygotowano także projekt ustawy „o wprowadzeniu rubrykowanych ksiag akt stanu cywilnego". Wydział prawodawczy departamentu legislatywnego rozsyłał także pisma do ministerstw o delegowanie swoich referentów na wspólne posiedzenia konferencyjne, np. „w spra- 
Biuro Ekonomiczne premiera miało być w zamierzeniu według statutu z 12 grudnia 1930 r. organem koordynującym prace polityczno-gospodarcze wszystkich ministerstw. Jego działalność dzieli się na okres: 1930 - połowa 1935 r. i od połowy 1935 r. do końca II RP, tj. do 1939 r.

Pierwszy okres charakteryzował się ,realizowaniem przez Biuro założeń statutu z 1930 roku”, w tym czasie prowadzono działalność w kierunku: załatwiania spraw z zakresu ekonomii napływających z poszczególnych resortów do rozstrzygania przez rząd, sprawy Komitetu Ekonomicznego Ministrów i szefa rządu, opracowywanie wniosków na posiedzenia gabinetu i Komitetu Ekonomicznego w kwestiach ekonomicznych wymagających inicjatywy premiera, sporządzanie dla niego sprawozdań o sytuacji gospodarczej państwa, realizowanie uchwał w zakresie spraw gospodarczych i sporządzanie $\mathrm{z}$ tego sprawozdań oraz załatwianie wszystkich spraw administracyjnych, jakie były rezultatem działalności Komitetu Ekonomicznego.

W celu realizowania powyższych zadań (zgodnie ze statutem z 12 grudnia 1930 r.) w Biurze Ekonomicznym funkcjonowało siedem referatów:

1. Referat do spraw przemysłu, handlu i rzemiosł;

2. Referat do spraw rolnictwa, leśnictwa i wytwórczości pokrewnej;

3. Referat do spraw skarbowości i finansów;

4. Referat do spraw komunikacji, poczt i telegrafów oraz robót publicznych;

5. Referat do spraw pracy i opieki społecznej;

6. Referat do spraw bezpośredniej działalności gospodarczej rządu i samorządu;

7. Referat do spraw ogólnosprawozdawczych ${ }^{39}$.

Jesienią 1935 r. rozpoczął się proces reorganizacji Rady Ministrów i zakres kompetencji oraz działalność Komitetu Ekonomicznego zaczął ulegać pewnej redukcji. Przykładem może być przeniesienie niektórych spraw załatwianych dotychczas w Biurze Ekonomicznym do Ministerstwa Skarbu, po tym jak stanowisko wicepremiera objął minister skarbu. Od tego czasu Biuro Ekonomiczne zajmowało się głównie obsługą inicjatywy gospodarczej rządu.

Według danych, w roku 1937 zakres spraw, jakimi zajmowało się Biuro Ekonomiczne obejmowal:

1. Bezpośrednią obsługę administracyjną premiera poprzez:

wie ustawy o organizacji statystyki administracyjnej w b. dzielnicy pruskiej”. Nierzadko przychodziły też wnioski z Ministerstwa Sprawiedliwości o przygotowanie projektów ustaw, np. „ustawy o zmianie niektórych przepisów, dotyczących aktów stanu cywilnego". W departamencie legislatywnym PRM przygotowywano bardzo różne projekty, m.in. dla Ministerstwa Robót Publicznych, np. projekt ustawy „o budowie kanałów rzek żeglownych i spławnych”, czy opiniowano projekt ustawy wodnej, przysłany z tegoż resortu, ibidem, Akta PRM, syg. 4843/23, 4508/ 22, 917/23, 1858/23, $24396 / 21$.

${ }^{39}$ Ibidem, t. 8, p. 11. 
a/ przekazywanie stałych danych o sytuacji gospodarczej kraju i zagranica, a także o działalności i zamiarach centralnych władz administracyjnych w sprawach polityki gospodarczej poprzez Główny Urząd Statystyczny, Instytut Badania Koniunktur Gospodarczych i ministerstw, którym podlegały sprawy gospodarcze;

b/ opracowywanie zagadnień zleconych przez szefa rząqu;

c/ realizowanie zleceń poszczególnych resortów (z tym że najważniejsze resorty gospodarcze delegowały do Biura swoich urzędników, pełniących rolę łączników i w pewnym stopniu referentów Biura do spraw danego ministerstwa).

2. Poza tym Biuro Ekonomiczne pełniło rolę sekretariatu Komitetu Ekonomicznego, po likwidacji (na posiedzeniu rządu w dniu 12 grudnia 1930 r.) odrębnego Sekretariatu Komitetu Ekonomicznego.

3. Do zadań Biura ekonomicznego należała także obsługa komisji, w których było ono reprezentowane na polecenie premiera lub Komitetu Ekonomicznego. Były to następujące komisje (w 1937 r.):

Komisja dla opracowania ,zasad polityki premiowania wywozu”, utworzona w 1936 r. (o charakterze ściśle poufnym);

Komisja dla spraw surowca dyktowego (utworzona w 1936 r., zlikwidowana w maju 1938 r.);

Komisja kontroli cen (utworzona w czerwcu 1937 r.);

Komisja cen przemysłowych przy Ministrze Przemysłu i Handlu;

Komisja dla spraw motoryzacji kraju;

Komisja dla spraw surowców krajowych;

Komisja dla sprawy czasu pracy w górnictwie węglowym.

Poza tym do zadań Biura Ekonomicznego należał udział w opracowywaniu i uzgadnianiu projektów ustaw i rozporządzeń oraz załatwianie spraw inwestycji publicznych, kwestii oddłużeniowych, handlu zagranicznego, polityki rolnej i budowy szkół, a także korespondencja PRM, w zakresie zagadnień gospodarczych. W 1937 r. skład Biura stanowili: dyrektor, dwóch urzędników referendarskich, trzech urzędników jako „siły pomocnicze” i kreślarz ${ }^{40}$.

Biuro Usprawnienia Administracji zajmowało się w początkach swojej działalności (zgodnie ze statutem z 12 grudnia 1930 r.) usprawnianiem metod pracy w urzędach państwowych, sprawami organizacji oraz zakresu działania władz i urzędów, dekoncentracji administracji, sporządzaniem opinii projektów ustaw i rozporządzeń, przeprowadzaniem usprawnień w administracji publicznej i załatwianiem spraw związanych z systemem kształcenia urzędników oraz obsadą personalną w urzędach. Sprawy personalne przeszły do Biura Personalnego PRM (dotychczas funkcjonował referat personalny w Biurze Usprawnienia Administracji, który zajmował się sprawami archiwum i skoro-

${ }^{40}$ Ibidem, p. 12, 13. 
widzem wraz ze sporządzaniem list osób zwolnionych z pracy. Natomiast do Biura Prezydialnego przeszły sprawy orderowe w latach 1934-1935 $5^{41}$.

Według zachowanych sprawozdań Biura (za rok 1937) przedmiotem jego działalności były następujące sprawy: opracowywanie dekretu o organizacji rządu, komasowanie niektórych prac rozdzielonych pomiędzy różne resorty (przykładem mogą być prace wodne, które podlegały aż trzem różnym resortom), sprawy z zakresu kompetencji departamentów w poszczególnych ministerstwach, ,w kierunku skoncentrowania nadzoru i odpowiedzialności w jednym departamencie za działalność niższych komórek jak przedsiębiorstwa państwowe, urzędy, itp.”, skasowanie zbędnych urzędów „odrębnych”, jak włączenie Urzędu Miar i Wag do resortu Przemysłu i Handlu, przesunięcie Prokuratorii Generalnej z resortu Skarbu do Prezydium Rady Ministrów (powrót do stanu z 1925 r.), sprawy podziału administracyjnego na województwa, ,zespolenie władz I i II instancji z władzami administracji ogólnej”, kwestie likwidacji zbędnych funduszy i przeszkód biurokratycznych w prowadzeniu ewidencji ludności, czy także np. koni (przy załatwianiu spraw meldunkowych na wsi rolnicy byli zobowiązani do wypełnienia aż ośmiu arkuszy, po dwadzieścia rubryk każdy). Należy dodać, że funkcjonowanie Biura Usprawnienia Administracji było dość ściśle związane z działalnością Komisji dla Usprawnienia Administracji Publicznej, działającej jako organ pomocniczy Prezydium Rady Ministrów, w latach 1928-1933 42 .

Biuro personalne utworzono z początkiem 1933 r. i w oparciu o II Statut PRM z 12 grudnia 1930 r. zakres jego działalności obejmował: koordynację współpracy biur personalnych we wszystkich ministerstwach, ustalanie przepisów i dyrektyw co do prac związanych z kwestiami organizacyjno-personalnymi dla wszystkich urzędów, jednostkowe sprawy personalne, jakie były zastrzeżone dla Prezydenta RP, premiera i rządu, nadzór nad budżetem personalnym wszystkich urzędów państwowych oraz sprawy awansów i orderów. Biuro to zajmowało się sprawami personalnymi pracowników Prezydium Rady Ministrów, ale z początkiem 1936 r. przekazano je do Biura Prezydialnego PRM. Ponadto Biuro dysponowało własną kancelarią, która w 1937 r. liczyła siedmiu urzędników z dyrektorem na czele oraz czterech referentów i trzech urzędników pomocniczych ${ }^{43}$.

Kolejną instytucją było Biuro Zadań Specjalnych, które utworzono w pierwszej połowie 1936 r., z tym że jego zakres kompetencji nie był jasno określony przepisami. Według zachowanych sprawozdań z działalności Biura w aktach PRM (za okres jego funkcjonowania od sierpnia do 10 grudnia 1936 r.) jednostka ta zajmowała się głównie przeprowadzaniem różnego ro-

\footnotetext{
${ }^{41}$ Ibidem, p. 13.

${ }^{42}$ Ibidem, p. 14.

${ }^{43}$ Ibidem.
} 
dzaju odczytów (przeważnie w największych miastach), najczęściej na środowiskowych zebraniach, np. w Związku Sybiraków; jednym z tematów była „Katorga aleksandrowska”, czy „Szlakiem Dywizji Syberyjskiej”, ale również wykorzystywano do tego drogę radiową. Działalność ta prowadzona była niemal jednoosobowo przez dyrektora tego Biura, Mieczysława Lepeckiego. Należy jeszcze dodać, że poza tym Biurem, w urzędzie Prezesa Rady Ministrów byli zatrudnieni także urzędnicy do zadań specjalnych ${ }^{44}$.

Kolejną jednostką było Biuro Polityki Narodowościowej, utworzone w oparciu o uchwałę rządu z 19 grudnia 1935 r., przez premiera Mieczysława Zyndrama-Kościałkowskiego, jako organ Komitetu do Spraw Narodowościowych, którym kierował szef gabinetu. Wraz z utworzeniem Biura, włączono do tej jednostki Biuro Organizacji Naukowych Badań Ziem Wschodnich, które zostało powołane w charakterze organu wykonawczego Komisji Naukowych Badań Ziem Wschodnich (którą utworzono uchwałą Komitetu do Spraw Narodowościowych w dniu 2 marca 1934 r.).

Podstawowym zadaniem Biura było ustalanie wytycznych polityki narodowościowej wobec różnych narodowości, pod kątem ich właściwości regionalnych. Funkcjonowanie tej jednostki można opisać w oparciu o sprawozdanie z działalności za czas od 9 listopada 1937 do 24 listopada 1938 r., w którym są też dane o jego wcześniejszych pracach. Zakres działalności Biura był dość szeroki i obejmował: wykonywanie wszelkich poleceń premiera w dziedzinie polityki narodowościowej, gromadzenie materiałów koniecznych dla prac Komitetu Narodowościowego w celu określenia konkretnych wytycznych polityki narodowościowej w stosunku do różnych narodowości, czuwanie nad wykonywaniem uchwał Komitetu Narodowościowego przez odpowiednie działy administracji państwowej oraz czuwanie nad przestrzeganiem ustalonych wytycznych, a także stałą koordynację tych działań pomiędzy poszczególnymi działami administracji i władzami państwowymi z czynnikami społecznymi (przede wszystkim czynnikami polskimi) ${ }^{45}$.

${ }^{44}$ M. Lepecki w okresie wymienionym w sprawozdaniu odbył podróż na Syberię, przywożąc ziemię na kopiec Józefa Piłsudskiego, ibidem, p. 15.

${ }^{45} \mathrm{~W}$ tym okresie Biuro Polityki Narodowościowej zajmowało się takimi sprawami, jak: działalność związana z połączeniem Zaolzia z Macierzą i zmianą granic państwa polskiego (współudział w pracach Komitetu Koordynacyjnego dla Spraw Śląska Zaolziańskiego), prace nad wykonaniem reformy rolnej na ziemiach mieszanych narodowościowo (szczególnie w b. Galicji wschodniej i b. zaborze pruskim), sprawy opieki nad polską ludnością ziem wschodnich (kupcy osiedleńcy, drobna szlachta zagrodowa, Kościoły rzymskokatolickie), prace nad ustaleniem nowego ustroju Kościoła prawosławnego II RP i jego wprowadzeniem w życie (także prowadzenie spraw politycznych odnoszących się do tego Kościoła), prace nad ustaleniem wytycznych w sprawach polityki wobec mniejszości niemieckiej w II RP (w związku z deklaracją z 5 listopada 1937 r. rządów III Rzeszy Niemieckiej i Rzeczypospolitej Polskiej), precyzowanie wytycznych w sprawach polityki władz państwowych i organów administracyjnych wobec społeczności kaszubskiej, współpraca z Komitetem dla Spraw Łemkowskich, podobne prace związane z problemami regionalnymi Bojkowszczyzny, sprawy udziału rozgłośni radiowej w zakresie propagandy wśród ludności ukraińskiej (audycja 
Ostatnim biurem PRM było Biuro Akcji i Planowania; nie jest znana data rozpoczęcia jego działalności, ale wiadomo, że zakończyło swoje funkcjonowanie w 1937 r. i najprawdopodobniej (dane są nieliczne) istniało zaledwie przez rok. W sprawozdaniu budżetowym PRM za rok 1937/38 można znaleźć informację, że Biuro to zajmowało się projektowaniem „metod celowo zorganizowanej akcji informacyjno-propagandowej, mającej na celu udostępnienie opinii publicznej śledzenie postępów prac nad rozwojem sił organizmu państwowego i wzrostem potęgi Rzeczypospolitej”. Skład tego Biura stanowiło kilka osób ${ }^{46}$.

Jak wspomniano Prezydium Rady Ministrów było w dużym stopniu ośrodkiem projektodawczym aktów prawnych, co potwierdzają konkretne liczby; w Sejmie Ustawodawczym (1919-1922) projekty Rady Ministrów stanowiły ponad połowę wszystkich zgłoszonych projektów ustaw do laski marszałkowskiej (na 1136 - 615, pozostałe to projekty sejmowe - 521), w Sejmie I kadencji (1922-1927) na 1025 wszystkich projektów ustaw - rządowe stanowily 649, a sejmowe - 376, w Sejmie II kadencji (1928-1930) na 453 projekty ustaw - projekty rządowe to 204 , a sejmowe - 249, w Sejmie III kadencji (1930-1935) na 685 projektów ustaw - projekty rządu to 581, a sejmowych było tylko 104, w Sejmie IV kadencji (1935-1938) - na 452 projekty ustaw rządowych projektów zgłoszono 305, a sejmowych 147 i wreszcie w ostatnim, V Sejmie II RP (1938-1939), na 133 projekt ustaw ogółem Rada Ministrów zgłosiła 104 projekty, a sejmowych było zaledwie 29. Zestawienie powyższych danych ukazuje, że poza Sejmem II kadencji we wszystkich pozostałych przeważały projekty rządowe ${ }^{47}$.

„Chwilka ukraińska”), współdziałanie w procesie emigracji z Polski ludności żydowskiej, prace nad uporządkowaniem relacji narodowościowych w spółdzielczości (szczególnie na ziemiach b. zaboru pruskiego), współpraca z organizacjami zajmującymi się opieką nad polskim stanem posiadania, tj. m.in.: Polskim Związkiem Zachodnim, Towarzystwem Rozwoju Ziem Wschodnich, Sekretariatem Porozumiewawczym Polskich Organizacji Społecznych we Lwowie i Światowym Związkiem Polaków z Zagranicy, prace nad ujednoliceniem opracowań kartograficznych w zakresie spraw narodowościowych i wyznaniowych i kontroli państwowej nad tym i wreszcie współudział w pracach Biura Planowania i Rady Naczelnej Obozu Zjednoczenia Narodowego, nad ustaleniem programu narodowościowego tej organizacji. Poza tym Biuro Polityki Narodowościowej zajmowało się także działalnością naukowo-badawczą, współuczestnicząc w pracach Komisji Naukowej Badania Ziem Wschodnich, Instytutu Badań Spraw Narodowościowych, Instytutu Gospodarczego Ziem Wschodnich, Instytutu Śląskiego, Wołyńskiego Instytutu Naukowego, Wydziału Pomorzoznawczego Instytutu Bałtyckiego i in., czy współorganizując m.in. II Zjazd Naukowy poświęcony polskim środkowym i wschodnim Karpatom. Do dodatkowych czynności Biura należało także załatwianie spraw bieżących, jak interpelacje poselskie, czy w resortach - w sprawach wynikających z jednorazowych poleceń (lub ogólnych), czy też poleceń szefa rządu lub Komitetu do Spraw Narodowościowych, AAN, p. 16, 17.

${ }^{46}$ Ibidem, p. 17, 18.

${ }^{47}$ Niewątpliwie na przewagę (niewielką zresztą) sejmowej inicjatywy ustawodawczej nad rządową w Sejmie II kadencji (1928-1930) wpływ miała dominacja posłów opozycyjnych, co z jednej strony niosło ryzyko odrzucenia projektów rządowych, ale z drugiej nie bez znaczenia była tutaj 
Jeśli mowa o inicjatywie ustawodawczej rządu, należy podkreślić, że nierzadko zdarzały się przypadki składania do laski marszałkowskiej kilku projektów ustaw w zakresie tej samej problematyki. Najczęściej były to projekty rządowe i komisji sejmowych lub, rzadziej, projekty rządu i posłów lub komisji i posłów ${ }^{48}$.

O roli Prezydium Rady Ministrów wiele mówi pamiętny spór pomiędzy marszałkiem Sejmu Ignacym Daszyńskim, a Józefem Piłsudskim, który jako premier postawił zarzut marszałkowi Sejmu (w kwietniu 1928 r.), że po objęciu swojej funkcji nie złożył wizyty głowie państwa; w odpowiedzi usłyszał, iż zgodnie z regulaminem do jego obowiązków należy przedstawienie się prezydentowi RP, którym był wówczas Ignacy Mościcki, ale po ukonstytuowaniu się Prezydium Rady Ministrów ${ }^{49}$. I to dodatkowo pokazuje, jak znaczącym organem w systemie ustrojowym Drugiej Rzeczypospolitej było Prezydium Rady Ministrów.

autorytarna postawa J. Piłsudskiego, który domagał się wstrzymywania wnoszenia projektów rządowych do Sejmu, P.A. Tusiński, Postępowanie ustawodawcze w Sejmie i Senacie II Rzeczypospolitej 1919-1939, Radom 2008, s. 114; R. Kraczkowski, Rozporzadzenia Prezydenta Rzeczypospolitej $z$ moca ustawy w latach 1926-1935, Warszawa 2007, s. $208 \mathrm{i}$ in.

${ }^{48}$ P.A. Tusiński, op. cit., s. 109.

49 T. Sikorski, Pierwszy Gabinet Józefa Piłsudskiego, (w:) Od Moraczewskiego do Składkowskiego. Gabinety Polski Odrodzonej 1918-1939, red. J. Faryś, A. Wątor, H. Walczak, Szczecin 2010, s. 240. 